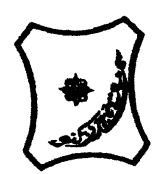

Bayero Journal of Pure and Applied Sciences, 11(1): 120 - 125

Received: November, 2017

Accepted: May, 2018

ISSN $2006-6996$

\title{
BIOACTIVE EFFECT OF Jatropha curcas L. LEAF PRODUCT ON Callosobruchus subinnotatus (Pic) INFESTING STORED BAMBARA NUT, Vigna subterranea (L.) Verdcourt
}

\author{
${ }^{* 1}$ Dattijo, S. A., ${ }^{2}$ Ahmed, B. I., ${ }^{3}$ Adebitan, S. A., ${ }^{4}$ Gurama, U. A. and ${ }^{5}$ Bichi, B. I. \\ ${ }^{1}$ Department of Pest Management Technology, Audu Bako College of Agriculture, Dambatta, \\ P. M. B. 3159, Kano, Kano State, Nigeria \\ ${ }^{2}$ Department of Crop Production, Faculty of Agriculture and Agricultural Technology, Abubakar TafawaBalewa \\ University, Bauchi, Bauchi State, Nigeria \\ ${ }^{3}$ Department of Crop Science and Horticulture, Faculty of Agriculture, Federal University Oye-Ekiti, Ekiti State, \\ Nigeria \\ ${ }^{4}$ Department of Agronomy, Faculty of Agriculture, Federal University Kashere, Gombe, Gombe State, Nigeria \\ ${ }^{5}$ Department of Agriculture, Audu Bako College of Agriculture, Dambatta, Kano, Kano State, Nigeria \\ Corresponding Author: abduljalaldattijo@yahoo.com +234 8034265435
}

\begin{abstract}
The research was conducted in the year 2016 at the Entomology laboratory of the Department of Crop Protection, Bayero University Kano to assessed the bioactive effect of physic nut, Jatropha curcas L. leaf powder on Callosobruchus subinnotatus (Pic) infesting stored bambara nut, Vigna subterranea (L.) Verdcourt. The study was also aimed at comparing the effectiveness of the leaf powder with conventional chemical insecticide (pirimiphos-methyl). In a $2 \times 2$ factorial experiment, the leaf powder and pirimiphos-methyl were admixed with bambara nut seeds. The first factor (leaves) had two (2) levels ( 0.0 and $0.5 \mathrm{~g} / 20 \mathrm{~g}$ seed) while the second factor (pirimipos-methyl) also had two levels, with and without the standard rate of application $(0.00$ and $0.01 \mathrm{~g} / 20 \mathrm{~g})$. These were laid out in a Completely Randomized Design and repeated three times. Results showed fumigant, repellant and contact effects were best exhibited in seeds treated with the leaf powder admixed at the rate of $0.5 \mathrm{~g}$, but was not significantly different from seeds treated with pirimiphosmethyl. In conclusion, appreciable level of protection on bambara nut seeds was achieved using the leaf powder of $\mathrm{J}$. curcas applied at $0.5 \mathrm{~g} / 20 \mathrm{~g}$ bambara nut seeds during storage.
\end{abstract}

Keywords: Bioactive, Callosobruchus subinnotatus, bambara nut, Jatropha, fumugant

\section{INTRODUCTION}

Grain legumes are important sources of plant protein and fat in tropical countries. They are good sources of essential amino acids and fats, the industrial application of which depends on the knowledge of their nutritional importance and functional properties (Aremu, et al., 2006). They serve as a cheap source of protein to a large proportion of the population in poor countries of the tropics (Amarteifio, 2006). For rural and urban dwellers in developing countries, they serve as least expensive non-processed protein sources, especially where animal protein is scarce and/or expensive (Rachie and Silvestre, 1997).

An indigenous African legume, whose origin is known to extend from Jos in Plateau and Yola in Adamawa states of Nigeria to Garoua in Cameroon (Goli, 1995), bambara groundnut, Vigna subterranea (L.) Verdcourt (Fabales: Fabaceae) has the potentials to provide a balanced diet where cultivation of other legumes is risky due to low rainfall (Quaye and Kanda, 2004). Bambara groundnut compares favourably in nutritional status with other well-known and highly commercialized beans and it is a good source of fibre, calcium, iron and potassium (Quaye and Kanda, 2004; Hillocks, et al., 2012). Sharing a high nutritive value with other widely consumed legumes, bambara groundnut also has an appealing flavour which is reflected in its demand from small local and niche markets (Hillocks, et al., 2012).

The crop has the potential to contribute to food security in view of its ability to withstand drought. This becomes more important especially in subSaharan Africa and some regions of the continent where rainfall is low to support most leguminous crops. Bambara groundnut is the most resistant pulse crop producing under conditions of high temperature and low rainfall where other pulses fail to survive (Doku and Karikari, 1971).

Although bambara groundnut has a reputation for resisting pests, Dike (1997) observed up to 16 insects pests on the crop in Samaru, Nigeria. He recorded six sucking bugs, Agonsoscelis versicolor Fab., Clavigralla tomentosicollis Stal., Mirperus jaculus Thunby, Locris rubens Erich, Macrorhapis acuta Dalm. and Poophilus spp. as prevalent pests during the reproductive stage of the crop. Bambara groundnut is also susceptible to infestation a by field-to-store insect pest, Callosobruchus subinnotatus (Pic) which often, simultaneously infest the crop together with Callosobruchus maculatus (Fab). However, in West Africa $C$. subinnotatus is more destructive to the crop (Lale and Vidal, 2001). 
Bajopas Volume 11 Number 1 June, 2018

For the protection of stored products against storage insect pests, botanicals, as alternatives to synthetic insecticides, however, information and scientific support on botanicals is generally inadequate and it is often difficult to recommend particular plant materials as a replacement for chemical insecticides because the efficacy levels of botanicals can vary from plant to plant, among storage pests, application methods and the stored products. This lead to the study on Jatropha curcas L. as protectant of bambara groundnut against $C$. subinnotatus during storage.

\section{MATERIALS AND METHODS \\ Preparation of Bambara Nut Seeds}

Fifty Kilogrammes of unshelled bambara nut, cream/brown eye variety seeds were purchased at a local market in Dambatta Local Government Area, Kano State. The seeds were decorticated manually. Shrivelled (shrunken) and damaged seeds as well as all other debris were removed. To disinfest the cleaned whole seeds, they were put in a polythene bag together with two phostoxin tablets (in an envelope) for 24 hours. The mouth of the bag was tied securely to ensure that any insect pest present within the seeds was killed according to the method of Ogunwolu et al., (2002). Thereafter, the seeds were opened and spread in a shaded well ventilated place for 48 hours to ensure that the seeds were free from the phostoxin residue. To avoid subsequent reinfestation and to ensure that any insect pest that might still remain within the seeds was killed the previously fumigated seeds were transferred into a fresh and different polythene bag and kept at $-4^{\circ} \mathrm{C}$ inside a fridge for four days (Ahmed, 2007).

\section{Collection of The Plant Leaves}

The leaves of the physic nut $J$. curcas were collected at the orchards of Audu Bako College of Agriculture, Dambatta, Kano State, while the Actellic dust was purchased from a pesticide store at Abubakar Rimi market, Sabon-gari, Kano, Kano State, Nigeria.

\section{Preparation of Plant Leaves}

The plant leaves were dried in shade to crispy condition. Thereafter, it was pounded in a mortar with pestle and then passed through a sieve $40 \mu \mathrm{mm}$ to give a very fine powder as described by Youdeowei (2004); Yusuf and Ahmed (2005). The fine powdered plant materials were kept in plastic bags until needed.

\section{Source and Rearing of Insect Culture}

The initial culture of the bambara nut bruchids was obtained from naturally infested bambara nut seeds at Kurmi market, Kano city, Kano State, Nigeria. A sample of the insects on infested seeds was taken to the insectary of the Department of Crop Protection, Ahmadu Bello University, Zaria, Kaduna State, Nigeria for proper taxonomic identification as Callosobruchus subinnotatus (Pic). These were then massively reared in transparent plastic buckets measuring $30 \mathrm{~cm}$ in height and $15 \mathrm{~cm}$ top diameter. The top end of the plastic buckets was covered with white muslin cloth, secured firmly into place with rubber bands, hence allowing for ventilation. These were incubated in Kliner jar at an ambient temperature and relative humidity $\left(32 \pm 3^{\circ} \mathrm{C}\right.$ and $57 \pm 3 \%$ respectively) with alternating light and dark cycle for 12 hours as previously described by Abduljalal et al. (2011).

\section{Experiment and Experimental Design}

Bioactive effect of the Jatrpha curcas leaves was assessed on Callosobruchus subinnotatus infesting stored bambara nut. The experiment was conducted in the Crop Protection Laboratory I, Faculty of Agriculture, Bayero University Kano State

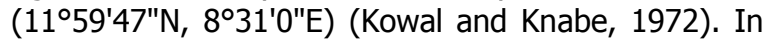
a $2 \times 2$ factorial experiment, the leaf powder of the Jatropha were assessed for the control of $C$. subinnotatus on stored bambara nut. The first factor (leaves) had two (2) levels ( 0.0 and $0.5 \mathrm{~g} / 20 \mathrm{~g} \mathrm{seed).}$ Similarly, the second factor (pirimipos-methyl) had two levels, with and without the standard rate of application $(0.00$ and $0.01 \mathrm{~g} / 20 \mathrm{~g})$. There were four (4) treatments replicated three (3) times in a completely randomized design. The setup was kept in the laboratory at ambient temperature and relative humidity of $32 \pm 3^{\circ} \mathrm{C}$ and $57 \pm 3 \%$, respectively.

\section{Assessment of the Potentials of The Plant Products \\ Contact Toxicity}

Methods described by Liu and Ho (1999); Juntarajumnong and Chandrapatya (2009) were adopted with some modifications (using chick feather instead of Burkard Arnold microapplicator and camel hair brush used by Liu and Ho; Juntarajumnong and Chandrapatya, respectively). The tested plant products were applied topically at the dorsal part of the thorax of $C$. subinnotatus adults using the chick feather, while control insects were left untreated. Both treated and control insects were placed into pure culture of bambara nut seeds. The number of dead insects was recorded daily for one week.

\section{Fumigant Toxicity}

Clean bambara nut seeds $(1 \mathrm{~kg})$ were selected and infested with 200 freshly hatched adult $C$. subinnotatus, which were removed after seven (7) days of oviposition. $20 \mathrm{~g}$ each of cream brown eye bambara nut variety bearing previously infested $C$. subinnotatus eggs were tied in a piece of muslin cloth and suspended inside 12 plastic bottles containing 0.5 $\mathrm{g}$ of both test plant products. The lids of the plastic bottles were covered in such a way that the muslin cloth containing the bambara nut seeds was suspended in space and not in contact with the test products. The set up was also made airtight by the aid of adhesive tape held around the lids of the plastic bottles (Plate 1). Untreated control (without the test plant products) was also similarly prepared. Number of adults that emerged from the previously laid eggs on the treated and untreated seeds was counted as described by Ofuya et al., (2010).

\section{Repellence Effect}

Half Whatman size filter paper (9 $\mathrm{cm}$ diameter) discs were prepared by cutting the filter paper into two equal halves and placed inside Petri dishes. One half of the disc of the filter paper contained extracts from $0.5 \mathrm{~g}$ of each of the test products (i.e. powdered leaves and seeds of Jatropha curcas and their combinations at $0.5: 0.5 \mathrm{~g}$ ) diluted in two $\mathrm{ml}$ of distilled water $(w / v)$. 
Similarly, two $\mathrm{ml}$ of distilled water only was added to the other half disc of the filter paper and used as untreated control. Both the treated and the untreated control halves were air-dried to evaporate the moisture completely. Each treated half was attached lengthwise, edge to edge to the control half disc with a thin strip of adhesive tape and placed in a Petri dish. The orientation of their seams was changed in the replicates to avoid the effect of any external directional stimulus affecting the distribution of the insects. Adult bruchids were released by the use of an aspirator onto the middle of each filter paper circle. For ventilation and visibility, transparent netted cloth were placed on top of the Petri dishes and held with rubber bands. Number of insects that moved and settled on each half of the filter paper was counted after one hour and then at hourly intervals for five hours as described by Liu and Ho (1999) and Juntarajumnong and Chandrapatya (2009).

\section{Data Analysis}

The data was subjected to One-way Analysis of Variance using computer software (SAS for windows) statistical package. Treatments with significant differences were compared and separated at $0.05 \%$ level of probability using Duncan's multiple range test (DMRT). Count data was transformed using Arcsine Vpercentage, as described by Gomez and Gomez (1976).

\section{RESULTS}

Bioactivity tests conducted showed the fumigation effect of the physic nut leaf powder, with and without the addition of actellic dust on the hatchability of eggs and emerged adult bruchids. Result presented in Table 1 showed significant difference $(p<0.01)$ among the treatments, with and without the actellic dust and between the treatments with the control. Number of hatched eggs (10.33) in $0.5 \mathrm{~g}$ leaf powder without the addition of actellic dust was similar to the number of hatched eggs (7.50) found in the check while both statistically differed from the number of hatched eggs found in the control. At the same time, least number of hatched eggs (5.50) that was statistically different from all of the treatments was observed with the use of $0.5 \mathrm{~g}$ leaf powder in which actellic dust was added. On the other hand, reduced number of live bruchids from the hatched eggs in the treatment, with and without actellic dust, including the check treatment (1.67, 0.50 and 0.50 , respectively) were similar, and significantly $(p<0.001)$ lower than the number of live bruchids (7.67) found in the control treatment.

At varied levels $(p<0.05, p<0.01$ and $p<0.001)$ of significance across hours, repellent effect was observed by using the leaf powder, with and without the addition actellic dust, as well as by the check and all treatments differ from the control. Moreover, statistically similar avoidance of treated surfaces was expressed by the bruchids in all of the treatments at all of the hourly intervals (Table 2). Contact toxicity effect of the leaf powder, with and without addition of the synthetic chemical, was presented in Table 3. After contact with the treatments, at two DAT, dead bruchids (5.67 and 5.83) observed in the leaf powder treatment, with and without the actellic dust were similar to that observed (6.33) in the check, and all these were significantly $(p<0.05)$ higher than that (4.00) in the control.

\section{DISCUSSION}

Positive bioactivity (mode of action) fumigation was observed in all the treatments, especially where $0.5 \mathrm{~g}$ leaf powder without the addition of the synthetic insecticide. Similar observations were also made by Constance et al. (2013) when the effects of J. curcas extracts on Sitophilus zeamais infesting maize grains was investigated. In their reports on the number of eggs hatched the different plant preparations (leaf and seed extracts $0-100$ ppm) significantly prevented egg hatching in a concentration-dependent manner. Grains pre-treated with Jatropha seed oil before storage bore the lowest number of hatched eggs and there was (Constance et al., 2013) no significant difference $(P<0.001)$ between the effects of the leaf extracts and that of the seed oil. Similarly, in an investigation on the effects of $J$. curcas on Sitophilus zeamais infesting stored rice grains, Asmanizar and Idris (2012) also reported that the two plant seed extracts (oil and powder) reduced $F_{1}$ progeny production suggesting that the extracts have the potential of protecting rice grain against $S$. zeamais infesting stored rice.

This study also showed that even without the addition of the synthetic insecticide, there was strong repellent effect by the two treatments, singly and combined together, which seemed to increase with time of exposure. The bruchids avoided the extracts; thereby suggesting that the plant extracts, singly and combined together may be used to protect bambara nut seeds as a repellent. The results of this study is in agreement with the findings of Don Pedro (1989; 1990) who earlier reported that some plant materials could be used to control storage insect pests' damage as repellents. Similarly, the findings of this study conformed with investigation conducted by Ogendo et al. (2003) on the efficacy of Lantana camara L. and Tephrosia vogelii Hook on S. zeamais infesting stored maize, where it was reported that $T$. vogelii was most repellent to $S$. zeamais at $7.5-10.0 \%(\mathrm{w} / \mathrm{w})$, repelling $87.5 \%$ of the insects, followed by $T$. vogelii at $2.5 \%$ $\mathrm{w} / \mathrm{w}$ and $L$. camara at $10 \% \mathrm{w} / \mathrm{w}$ which repelled 65.0 and $62.5 \%$ of insects, respectively.

The investigation also revealed that all the treatments indicated that there was toxic contact effect on the bruchids. Quick mortality was caused by using the leaf extract, where treated bruchids died within $72 \mathrm{~h}$ of application. Similarly, Araya and Emana (2009) reported that hundred percent mortality of $Z$. subfasciatus was obtained with $C$. ambrosioides leaf powder at all levels of concentrations $24 \mathrm{~h}$ after treatment and more than $90 \%$ mortality of adult $Z$. subfasciatus was also observed for bean seeds treated with J. curcas, $D$. stramonium and $P$. dodecondra $96 \mathrm{~h}$ after treatment.

\section{CONCLUSION}

From the findings of this study, it could be concluded that leaf powder of $J$. curcas, with and/or without any addition of the actellic dust $2 \%$, was bio-actively effective for the management of $C$. subinnotatus infesting stored bambara nut. 
Advantage of these modes of action against the bruchid could be economically viable to use the powder as bio pesticides for the control of $C$. subinnotatus infesting bambara nut. This could also provide a management strategy that will lead to reduction in the quantity of environmentally unfriendly synthetic insecticides used to control the bruchid during storage.

\section{RECOMMENDATIONS}

From the findings of this study that:

i. the leaf extracts of J. curcas, singly and combined with reduced rate of pirimiphosmethyl, could be mixed with bambara nut seeds during storage;

ii. in hermetic storage environment, leaf powder singly, at the rate of $0.5 / 20 \mathrm{~g}$ could be used to fumigate bambara nut seeds in order to reduce the hatchability of the bruchid's eggs and hatched adults;

iii. for repellence effect, the leaf powder, singly, especially at $0.5 / 20 \mathrm{~g}$ grains, could be adopted to repel the bruchids and as protectant of bambara nuts during storage;

\section{REFERENCES}

Abduljalal, D. S., Ahmed, B. I., Yusuf, S. R. and Abdullahi, U. (2011). Laboratory evaluation of insecticidal potentials of kane plant, Anogeissus leiocarpus Guil.and Perr. againstbambara nut bruchid, Callosobruchus subinnotatus (Pic.) on stored bambara nut, Vigna subterranea (L.) Verdcourt. Nigerian Journal of Entomology, 28: 75-84.

Ahmed, B. I. (2007). Potentials of entomopathogenic fungi in controlling the menace of maize weevil, Sitophilus zeamais Motsch.(Coleoptera: Curculionidae) on stored maize grain. Archives of Phytopathology and Plant Protection, 52(8): 750-758.

Amarteifio, J. O., Tibe, O. and Njogu, R. M. (2006). The chemical composition of bambaranut (Vigna subterranea L. Verdcourt) grown in south Africa. African Journal of Biotechnolog, 5(23): 2408-2411.

Araya, G. and Emana, G. (2009). Evaluation of botanical plants powders against Zabrotes subfasciatus (Boheman) (Coleoptera: Bruchidae) in stored haricot beans under laboratory condition. African Journal of Agricultural Research, 4(10): 1073-1079.

Aremu, M. O., Olaofe, O. and Akintayo, E. T. (2006). Chemical composition and physiochemical characteristics of two varieties of bambaranut (Vigna subterranea) flour. Journal of Applied Sciences Research, 6(9): 1900-1903.

Asmanizar, A. D. and Idris A. B. (2012). Evaluation of Jatropha curcas and Annona muricata seed crude extracts against Sitophilus iv. finally, further research is recommended in order to fully understand the mechanism of action produced by the plant extract in the bruchids.

\section{Contribution of Authors}

Dattijo, S. A. conceived the concept of this research, designed and acquired data, as well as analysis of the data. Ahmed, B. I., Adebitan, S. A. and Gurama, U. A. encouraged the investigation, supervised the findings of this work, verified the analytical methods and assist reviewed, critically, the intellectual content of the final manuscript of this article and give final approval for the version submitted for publication.

\section{Conflict of Interest}

In accordance with Taylor and Francis policy and my ethical obligation as researcher, I am reporting that, in the conduct of this research, I enjoyed the use of facilities, equipment and personnel resources of the Department of Crop Protection, Faculty of Agriculture, Bayero University Kano, Kano State, Nigeria, a University that may be affected by the research report in this paper. I have in place an approved document for managing any potential conflict that may arise from this research

zeamais infesting stored rice. Journal of Entomology, 9(1): 13-22.

Azam-Ali, S. N., Sesay, A., Karikari, S. K., Massawe, F. J., Aguilar-Manjarrez, J., Bannayan, M. and Hampson, K. J. (2001). Assessing the potential of an underutilized crop - a case study using bambara nut. Experimental Agriculture, 37(4): 433-472.

Constance C. J., Daniel T. G. and Opeolu O. O. (2013). Extracts of Jatropha curcas L. exhibit significant insecticidal and grain protectant effects against maize weevil, Sitophilus zeamais (Coleoptera: Curculionidae). Journal of Stored Products and Postharvest Research, 4(3): 44-50.

Dike, M. C. (1997). Effect of insect pests on pod and seed yields of bambara nut, Vigna subterranea (L.) Verdc. in Nigeria. International Journal of Pest Management, 43(3): 191-192.

Doku, E. V. and Karikari, S. K. (1971). Bambara nut. Economic Botany, 25(3):225-262.

Don Pedro, K. N. (1989). Mechanism of action of some vegetable oils against Sitophilus zeamais Mostch. (Coleoptera: Curculionidae) on wheat. Journal of Stored Products Research, 25: 217-223.

Don Pedro, K. N. (1990). Insecticidal property of fatty acid constituents of fixed vegetable oils against Callosobruchus maculatus (F.) on cowpea. Pesticide Science, 39: 295-302.

FAO, (2001). Targeting for nutrition resources for advancing well being. Food and Agricultural Organization, Rome, UN. www.fao.org/DOCREP/004/Y1329E/y1329e0 $\underline{0 . h t m}$. 
Goli, A. E. (1995). Bambara nut (Vigna subterranea (L.) Verdc.): Heller, J., Begemann, F. And Mushonga, J. (Eds.).In: Proceedings of the workshop on conservation andimprovement of bambaranut (Vigna subterranea (L.) VerdC.) $14^{\text {th }}-16^{\text {th }}$ November, 1995. Harare, ZimbabwePromoting the conservation and use of underutilized crops No 9. Proceedings of the workshop on the conservation of bambaranut, International Plant Genetic Resources Institute, Rome, Italy. $166 \mathrm{pp}$.

Gomez, K. A. and Gomez, A. A. (1976). Statistical procedures for agricultural research with emphasis on rice. The International Rice Research Institute, Los Banos, Laguna, Philippines, P. O. Box 933, Manila Philippines. 317pp.

Hillocks, R. J. Bennett, C. and Mponda, O. M. (2012). Bambara nut: A review of utilisation, market potential and crop improvement. African Crop Science Journal, 20(1): 1 - 16.

Juntarajumnong, K. K. W. and Chandrapatya, A. (2009). Repellency, fumigant and contact toxicities of Melaleuca cajuputi Powell against Sitophilus zeamais Motschulsky and Tribolium castaneum Herbst. Thai Journal of Agricultural Science, 42(1): 27-33.

Kowal, J. M. and Knabe, D. T. (1972). $A n$ Agroclimatological Atlas of Northern Nigeria (With Explanatory Notes). Ahmadu Bello University Press, Zaria, Nigeria. 111pp.

Lale, N. E. S. and Vidal, S. (2001). The impact of storage insect pests on post-harvest losses and their management in the Nigerian agricultural system. A Symposium Paper Presented At the $32^{\text {nd }}$ Annual Conference of The Entomological Society of Nigeria. National Library, Bida Road, Kaduna, 8-11 October, 2001. 14pp.

Liu, Z. L. and Ho, S. H. (1999). Bioactivity of the essential oil extracted from Evodia rutaecarpe Hook. f. et. Thomas against the train storage insects, Sitophilus zeamais Mostch. and Tribolium castaneum (Herbst.). Journal of Stored Product Research, 35: 317328.

Mwale S. S., Azam-ali, S. N. and Massawe, F. J. (2007). Growth and development of bambara nut (Vigna subterranea) in response to soil moisture, dry matter and yield. European Journal of Agronomy, 26: 345-353.

Ofuya, T .I, Olotuah O. F. and Akinyoade, D. O. (2010). The effect of storage on the efficacy of Eugenia aromatica (Baill.) in the control of (2): $180-187$.
Callosobruchus Maculatus (Fabricius) (Coleoptera: Bruchidae) pest. Journal of Applied Science and Environmental Management, 14(1): $97-100$.

Ogendo, J. O., Belmain, S. R., Deng, A. L. and Walker, D. J. (2003). Comparison of toxic and repellent effects of Lantana camara L. with Tephrosia vogelii Hook and a syntheticpesticide against Sitophilus zeamais Motschulsky(Coleoptera: Curculionidae) in stored maize grain. Insect Science and its Application, 23(2): 127-135.

Ogunwolu, E. O., Aku, A. A., Attah, J. and Igoli J. O. (2002). Control of seed bruchid, Callosobruchus maculatus $\mathrm{F}$. infestation in cowpea, Vigna unguiculata (L.)Walp.With Clausena anisata Hook (Rutaceae). Bioscience Research Communication, 14(2): 205- 211.

Quaye, W. and Kanda, I. J. 2004. Bambara marketing marginal analysis. Project Report - high quality bambara flour technology transfer project. DFID Crop Post Harvest Programme and Food Research Institute, Accra, Ghana.41 pp.

Rachie, K. O. and Silvestre, P. (1997).Grain legumes. In: Leakey, C. L. A. and Will, J. B. (Eds). Food Crops of the Lowland Tropics. Oxford University Press, Oxford. Pp: 41-74.

Shaaya, E., Ravid, U. Paster, N., Juven,B. Zisman, U. and Pissarev, V. (1991). Fumigant Toxicity of Essential Oils against Four StoredProducts Insects. Journalof Chemical Ecology, 17: 499-504.

Swanevelder, C. J. (1998). Bambara - Food for Africa. National Department of Agriculture, Resource Centre Directorate of Communications, Private Bag X144, Pretoria 0001, South Africa. 16pp.

Thottappilly, G. and Rossel, H. W. (1997). Identification and characterisation of viruses infecting bambara nut (Vigna subterranean) in Nigeria. International Journal of Pest Management, 43: 177 185.

Youdeowei, A. (2004). Principles of Integrated Pest Management: Growing Healthy Crops. Ministry of Food and Agriculture (MOFA), Plant Protection and Regulatory Services Directorate (PPRSD), Ghana, With German Development Cooperation. 31pp.

Yusuf, S. R. and Ahmed, B. I. (2005). Effects of application rates of some plant materials on the control of maize weevil (Sitophilus zeamais Mots.) in stored maize. Journal of Pure and Applied Science, 
Table 1: Fumigation Effect of Jatropha curcas Leaf Extract With and Without Synthetic Chemical Application on Hatchabity of Eggs and Emerged Adults of Callosobruchus subinnotatus

\begin{tabular}{|c|c|c|c|}
\hline \multicolumn{2}{|c|}{ Treatment } & \multirow{2}{*}{$\begin{array}{c}\text { Number of hatched } \\
\text { eggs }\end{array}$} & \multirow{2}{*}{$\begin{array}{c}\text { Number of } \\
\text { living insects }\end{array}$} \\
\hline $\begin{array}{c}\text { Leaf } \\
\text { powder(g) }\end{array}$ & Pirimiphos-methyl(g) & & \\
\hline 0.0 & 0.00 & $13.00^{\mathrm{a} \Omega}(21.13)$ & $7.67^{\mathrm{a} \Omega}(16.00)$ \\
\hline 0.0 & 0.01 & $7.50^{\mathrm{bc}}(15.89)$ & $0.50^{\mathrm{b}}(1.28)$ \\
\hline 0.5 & 0.00 & $10.33^{\mathrm{ab}}(18.72)$ & $0.50^{\mathrm{b}}(1.28)$ \\
\hline 0.5 & 0.01 & $5.50^{c}(13.56)$ & $1.67^{\mathrm{b}}(7.27)$ \\
\hline \multicolumn{2}{|c|}{ *L.S. } & $* *$ & $* * *$ \\
\hline \multicolumn{2}{|c|}{ SE士 } & 1.498 & 0.706 \\
\hline
\end{tabular}

$\Omega$ Means within a column followed by different letters are statistically significantly different at $* *=P \leq 0.01$ and $* * *$

$=\mathrm{P} \leq 0.001$, Duncan's multiple range test.

${ }^{\circ}$ Figures in parentheses are Arcsine $\sqrt{ }$ percentage transformations.

*L.S = level of significance.

Table 2: Repellence effect of Jatropha curcas Leaf Extract With and Without Synthetic Chemical Application on Adults of Callosobruchus subinnotatus

\begin{tabular}{lcccccc}
\hline & Treatment & \multicolumn{5}{c}{ Repellence effect hours after treatment (HAT) } \\
\hline $\begin{array}{c}\text { Leaf } \\
\text { powder(g) }\end{array}$ & Pirimiphos-methyl(g) & $\mathbf{1}$ & $\mathbf{2}$ & $\mathbf{3}$ & $\mathbf{4}$ & $\mathbf{5}$ \\
\hline 0.0 & & & & & & \\
& 0.00 & $5.83^{\mathrm{a} \Omega}$ & $6.17^{\mathrm{a}} \Omega$ & $6.33^{\mathrm{a} \Omega}$ & $5.83^{\mathrm{a} \Omega}$ & $5.50^{\mathrm{a} \Omega}$ \\
0.0 & & $(13.94)$ & $(14.30)$ & $(14.54)$ & $(13.94)$ & $(13.56)$ \\
& 0.01 & $2.17^{\mathrm{b}}$ & $2.00^{\mathrm{b}}$ & $1.33^{\mathrm{b}}$ & $1.83^{\mathrm{b}}$ & $1.17^{\mathrm{b}}$ \\
0.5 & & $(8.33)$ & $(8.13)$ & $(6.55)$ & $(7.71)$ & $(6.02)$ \\
& 0.00 & $1.83^{\mathrm{b}}$ & $2.83^{\mathrm{b}}$ & $2.50^{\mathrm{b}}$ & $1.83^{\mathrm{b}}$ & $1.17^{\mathrm{b}}$ \\
0.5 & & $(7.71)$ & $(9.63)$ & $(9.10)$ & () 7.71 & $(6.02)$ \\
& 0.01 & $1.83^{\mathrm{b}}$ & $1.17^{\mathrm{b}}$ & $1.17^{\mathrm{b}}$ & $1.67^{\mathrm{b}}$ & $2.17^{\mathrm{b}}$ \\
& & $(7.71)$ & $(6.02)$ & $(6.02)$ & $(7.27)$ & $(8.33)$ \\
& & $* *$ & $*$ & $*$ & $*$ & $* *$ \\
& L.S. $^{*}$ & 0.503 & 0.605 & 0.654 & 0.664 & 0.539 \\
\hline
\end{tabular}

${ }^{\Omega}$ Means within a column followed by different letters are statistically significantly different at $*=\mathrm{P} \leq 0.05, * *=$ $\mathrm{P} \leq 0.01$ and $* * *=\mathrm{P} \leq 0.001$, Duncan's multiple range test.

${ }^{\circ}$ Figures in parentheses are Arcsine $\sqrt{ }$ percentage transformations.

${ }^{*}$ L.S $=$ level of significance.

Table 3: Contact Effect of Jatropha curcas Leaf Extract With and Without Synthetic Chemical Application on Adults of Callosobruchus subinnotatus

\begin{tabular}{lccc}
\hline & Treatment & \multicolumn{2}{c}{ Contact effect days after treatment (DAT) } \\
\hline $\begin{array}{c}\text { Leaf } \\
\text { powder(g) }\end{array}$ & Pirimiphos-methyl(g) & $\mathbf{2}$ & $\mathbf{3}$ \\
\hline 0.0 & & & $4.00^{\mathrm{a} \Omega}(11.54)$ \\
0.0 & 0.00 & $3.67^{\mathrm{a} \Omega}(10.94)$ & $6.33^{\mathrm{b}}(14.54)$ \\
0.5 & 0.01 & $4.00^{\mathrm{a}}(11.54)$ & $6.00^{\mathrm{b}}(14.18)$ \\
0.5 & 0.00 & $5.83^{\mathrm{b}}(13.94)$ & $6.83^{\mathrm{b}}(15.12)$ \\
& 0.01 & $5.67^{\mathrm{b}}(13.69)$ & $*$ \\
& L.S. & $*$ & 0.442 \\
\hline
\end{tabular}

Means within a column followed by different letters are statistically significantly different at $*=P \leq 0.05$, Duncan's multiple range test.

${ }^{\circ}$ Figures in parentheses are Arcsine $\sqrt{ }$ percentage transformations.

*L.S = level of significance. 